\title{
AWÊ DE ENCANTARIAS: A EXPERIÊNCIA DE UM LIVRO VIVO COM CRIANÇAS PATAXÓ
}

\author{
Laura Castro de Araujo ${ }^{1}$
}

Carolina Ferreira Fonseca²

\begin{abstract}
RESUMO: Este é um relato de experiência sobre a construção da história YAMANI, publicada no livro "Kijetxawê Zabelê - Aldeia Kaí", em 2019, e construído juntamente com as crianças da comunidade pataxó da Aldeia Kaí. O texto parte do processo de construção poético dessa história e se enreda em vivências no território expandido da escola Kijetxawê Zabelê, com o intuito de pensar a presença do imaginário dos encantados entre as crianças da comunidade, assim como refletir sobre a experiência de criação de um livro vivo. $O$ trabalho descreve procedimentos de criação coletiva com as crianças, assim como documenta suas etapas de criação, ao passo em que reflete sobre a escola como espaço expandido da aldeia.
\end{abstract}

Palavras-chave: Infância. Pataxó. Livro.

\section{AWÊ DE ENCANTARIAS: AN EXPERIENCE OF A LIVE BOOK WITH PATAXÓ CHILDREN}

ABSTRACT: This is an experience report on the construction of the YAMANI story, published in the book "Kijetxawê Zabelê - Kaí Village", in 2019, and elaborated together with the children from pataxó community, in Aldeia Kaí. The text approach the process of poetic creation of this story and enters into experiences in the expanded territory of the Kijetxawê Zabelê school, in order to think about the presence of the enchanted imaginary among the children of the community, as well as to reflect on the experience of creating an idea of "an alive book". The paper describes collective creation procedures with children, as well as documents stages of creation, while reflecting on the school as expanded village space.

Keywords: Infancy. Pataxó. Book.

\footnotetext{
${ }^{1}$ Graduada em Letras. Doutora em Artes Cênicas pela UFBA. É professora adjunta no Instituto de Humanidades, Artes e Ciências (IHAC) da UFBA. E-mail: professoralauracastro@gmail.com

${ }^{2}$ Designer. Doutora em Arquitetura e Urbanismo. Professora adjunta da Faculdade de Artes Visuais da UFG. E-mail: caca.fonseca@gmail.com
} 


\section{AWÊ DE ENCANTARIAS: LA EXPERIENCIA DE UN LIBRO VIVO CON NIÑOS PATAXÓ}

RESUMEN: Este es un relato de experiencia sobre la construcción de la historia de YAMANI, publicado en el libro "Kijetxawê Zabelê - Kaí Village", en 2019, y construido junto con los niños de la comunidad pataxó de Kaí Village. El texto parte del proceso de construcción poética de esa historia y entra en experiencias en el territorio expandido de la escuela Kijetxawê Zabelê, para pensar en la presencia del imaginario encantado entre los niños de la comunidad, así como para reflexionar sobre la experiencia de crear una especie de libro vivo. El trabajo describe los procedimientos de creación colectiva con niños, así como documenta sus etapas de creación, mientras reflexiona sobre la escuela como un espacio expandido de la aldea.

Palabras clave: Infancia. Pataxó. Libro.

\section{Prenúncio do Awê}

Essa história começa, mas não acaba, conta de um encantamento feito magia, dessas coisas que acontecem e não se explicam. São um tanto de caminhos, poesias e músicas de fazimento das miragens. Era junho, mas era também outro tempo sem nome de mês, tinha vento, sol e chuva, sem casamento de viúva.

Foi na Kijetxawê Zabelê, ali na beira da estrada, vizinhança de mata, plantada debaixo do pé da gameleira e em cima de um chão de luta e força. Ali, era lugar apinhado de encantos. Esse surgimento veio primeiro de uma ciranda de desenhos, formada em roda na mesa, onde Xica, Janaíri, Keilinha, Laís, Aurora, Cacá e Laura giravam os papéis e os desenhos se faziam de traço em traço a 12 mãos. Alguém anunciava o já e a dança dos papéis recomeçava, até que completamos um giro inteiro e lá estavam seis encantados, vindos de um encantamento de desenho coletivo. Depois da ciranda, a coleta, que encheu as mãos de Xica, Janairi, Keilinha, Laís e Aurora de urucum, girassol, palha de capim, favo de semente e sementes. 
E é dessa força colhida nas mãos das kitokes que nasceu uma vó da mata bonita, com um arco de pétalas cor-de-rosa no cabelo, levava uma lança na mão, feito guerreira que é, e umas rajadas vermelhas de urucum, que the arrodeavam de feitiço. Nasceu junto uma caipora com os cabelos de favas de semente e os olhos de fogo, um boitatá mascarado, com rabo de fibra de palmeira serpenteante, a mãe d'água sereiou uma cauda de carimbo, com escamas de alfabeto, flores e mais uma companhia, um peixe tão azul, quase mar.

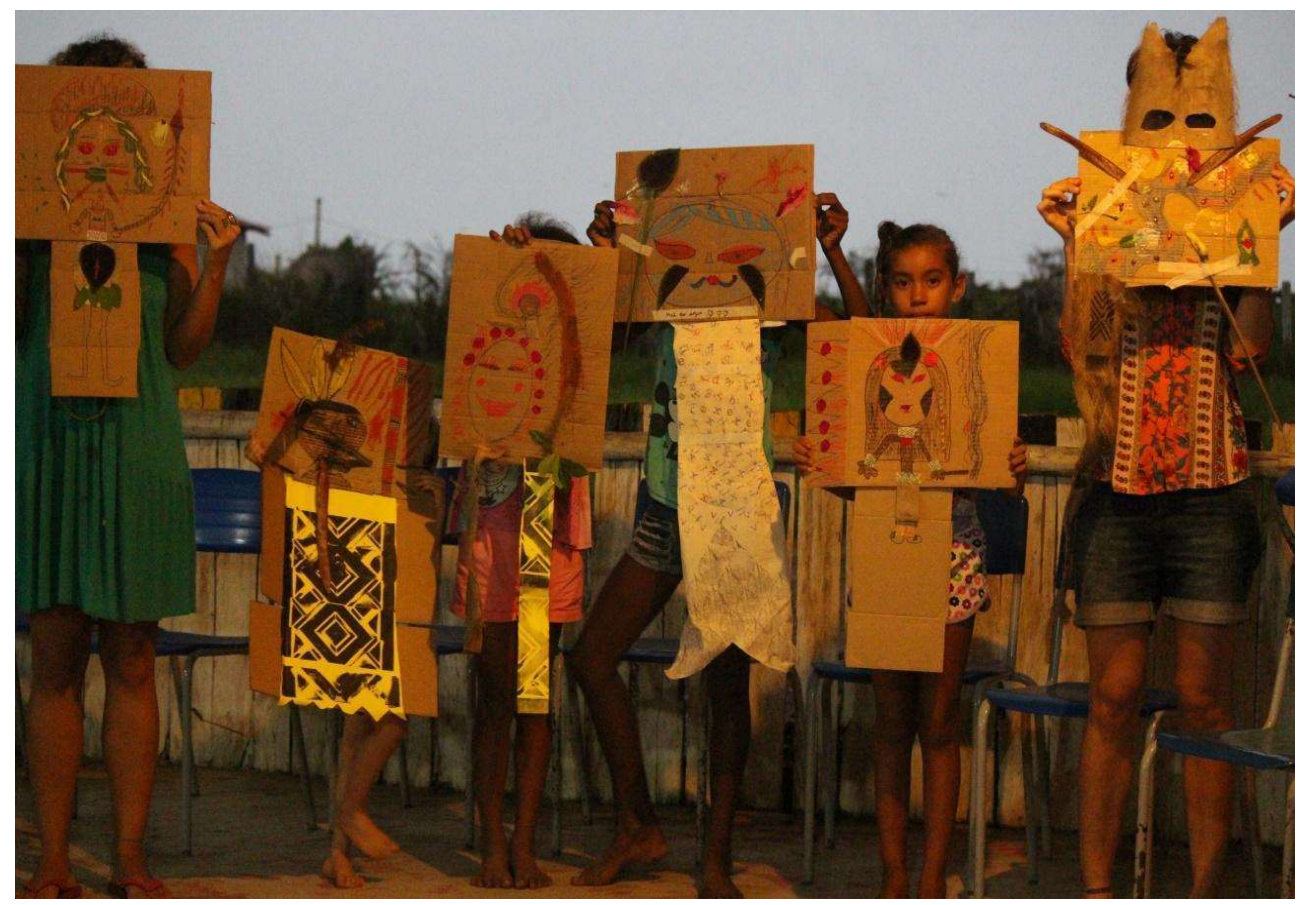

Figura 1 - Crianças no fim do dia de construção dos encantados. Fonte: Acervo do projeto "Edições Zabelê" (foto de Tamykuã Pataxó).

\section{Do contexto de encantamentos: as crianças e os caminhos de criação}

O texto que abre este relato de experiência é retirado do livro "Kijetxawê Zabelê - Aldeia Kaí", publicado em 2019, e construído juntamente com estudantes e professores do Colégio Estadual Indígena Kijetxawê Zabelê, especificamente o anexo 
da Aldeia Kaí (CASTRO; FONSECA, 2019, p. 34). Ele abre uma das partes do livro, a história infantil YAMANI, construída coletivamente com as crianças da aldeia, que conta as aventuras da mãe d'água, um dos seres encantados mais presentes nas vivências que fizemos no contexto desse projeto, que desaguou na publicação em questão.

Mas, para entender o percurso, comecemos do início. O projeto de fundo dessa experiência, intitulado Edições Zabelê, tinha como objetivo construir uma publicação a partir de oficinas e vivências diversas de um grupo de artistas e professores com a comunidade escolar da Zabelê, na Aldeia Kaí. Um livro que, construído no coração da escola, pudesse retornar a ela e a muitas outras no Estado da Bahia, quem sabe em todo o país. A partir disso, organizamos algumas imersões no território, no contexto de uma residência artístico-pedagógica.

Muitos caminhos se abriram, algumas rotas foram possíveis, mas talvez a experiência mais marcante desse processo criativo partilhado tenha sido nas nossas trocas com as crianças, que, sempre muito amorosas e muito receptivas a nossa presença na aldeia, além de muito entusiastas das oficinas, possibilitaram, sem dúvida, a primeira relação afetiva que criamos, enquanto grupo, na Aldeia Kaí. Logo de início, Talita Oliveira, jovem da comunidade que integrava a equipe de artistas do projeto, como fotógrafa, fez uma fala emocionada que nos tocou muito. Ela estava engajada em uma pesquisa sobre as mulheres do território e nos falou sobre a dificuldade de se deparar apenas com as histórias de lutas, muitas vezes sofridas e dolorosas, e pouco se falar dos encantados, da poesia que existia ali.

Tempos depois, ela nos revelou que os encantados eram relações vivas que a colonização foi incapaz de matar, tornando-se os sobreviventes míticos e as forças criadoras da possibilidade de resistência Pataxó. Sem dúvida, esse momento foi um guia para nossa escuta a partir de então. Uma das proposições que fizemos às crianças, 
por exemplo, foi fazermos uma oficina de escrita criativa na turma de Educação Infantil da escola, usando os encantados como mote para a construção de histórias.

A oficina foi conduzida, primeiramente, da seguinte forma. A ideia era que as próprias crianças dissessem quais encantados elas conheciam. Fizemos alguns papéis coloridos, criamos uma espécie de alfabeto efêmero e colocamos, na lousa, os encantados. $O$ interessante foi que, entre os nomes escolhidos pelas crianças, havia especificidades na amostragem desse relicário de encantados. Além da mãe d'água, do boitatá, do curupira, nomes para nós mais populares, apareceram alguns novos como a vó da mata e outros que indicavam encantados do próprio território, como a pajé Jovita, Zabelê, anciã que dá nome à escola, e o Monte Pascoal.
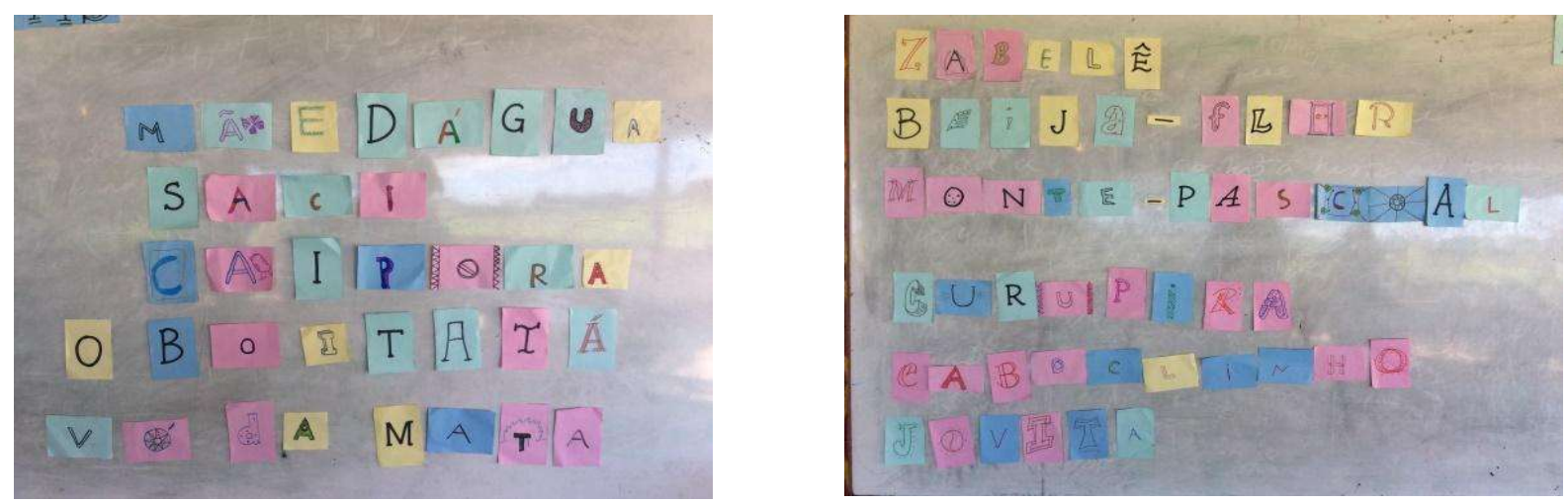

Figuras 2 e 3 - Oficina de Escrita Criativa com as crianças do Ensino Fundamental. Fonte: Acervo do projeto "Edições Zabelê" (foto de Laura Castro).

Feito isso, começamos a construir, oralmente, uma história coletiva, que copiamos abaixo, na íntegra.

Duas bruxas - Fernanda e Maria - apareceram no Monte Pascoal. A vó da mata apareceu e disse a elas: - Vão embora agora! Então, as bruxas voaram com uma vassoura de cipó. Foi então que encontraram o saci no meio do caminho. Estava chovendo muito. Até trovão. E o saci falou: _ comam um javali e vocês vão ficar 
encantadas. As bruxas botaram um feitiço no saci então. A vó da mata chega e bota um feitiço nas bruxas para elas virarem rato. Então, elas viram rato. O Sol aparece e ponto final.

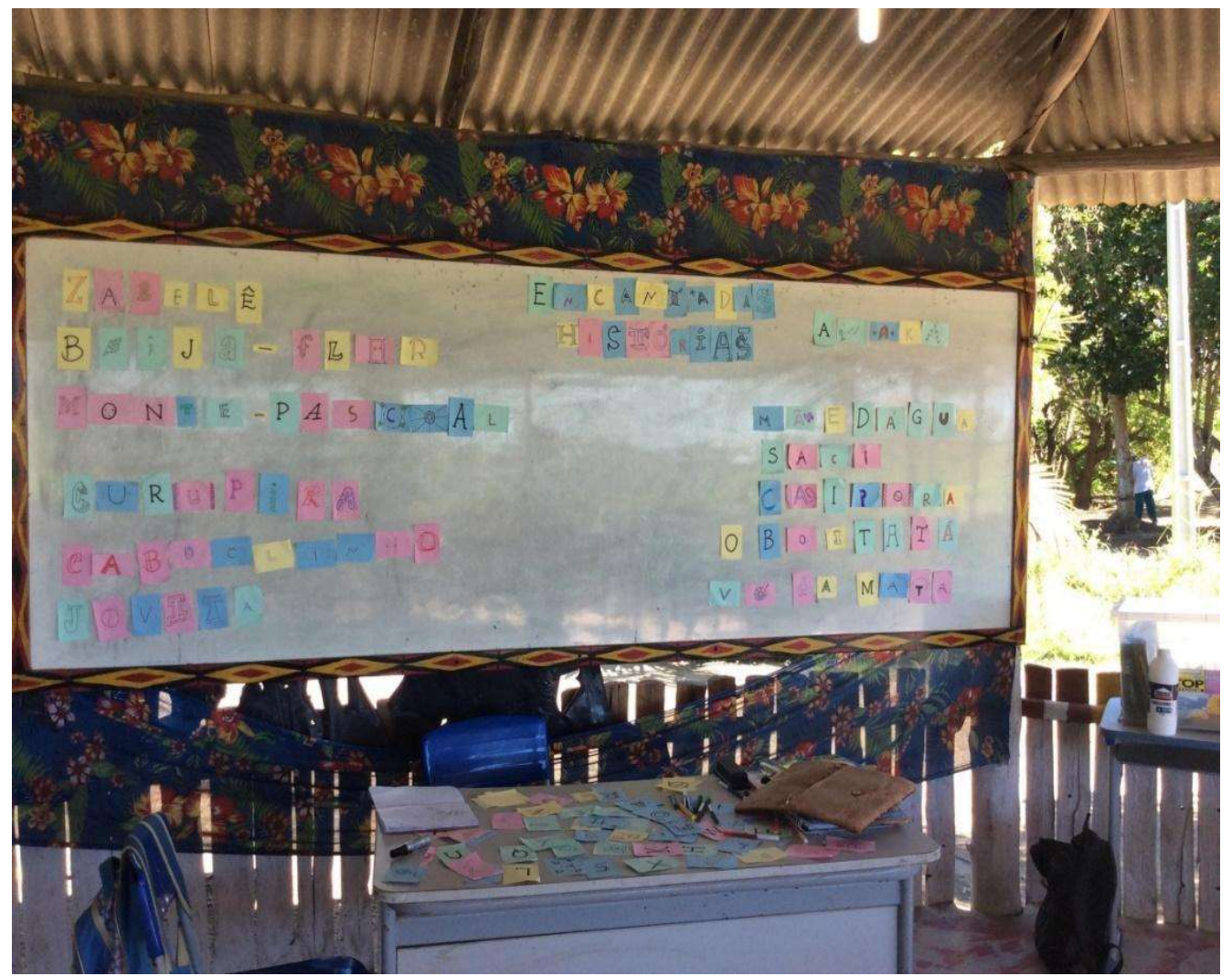

Figura 4 - Oficina de Escrita Criativa com as crianças do Ensino Fundamental. Fonte: Acervo do projeto "Edições Zabelê" (foto de Laura Castro).

Essa história foi construída como uma costura de muitas falas, alguém dava uma ideia, outra pessoa dava outra, discutíamos e negociávamos, muitos sorriam. Alguns puxavam de canto e, por vezes, contavam que tinham visto ou conheciam alguém que já tinha encontrado um encantado, um primo, uma tia etc. Depois dessa oficina, essa prática se tornou comum e passamos a conversar sobre isso, sobretudo com algumas crianças na aldeia. 
O contraponto, dentro da comunidade, dos narradores das cosmologias dos encantados da Aldeia Kaí, eram, justamente, os anciões que, assim como as crianças, gostavam muito de compartilhar conosco histórias sobre os encantados.

\section{Rodada de desenhos ou a ciranda dos encantados}

Muito instigadas pelas conversas que tínhamos sobre os seres encantados, um dia, fomos até a aldeia, no fim de semana, e fizemos uma roda de desenho coletivo. Cada criança sorteava o nome de um encantado e começava a desenhá-lo. Em um dado momento, parávamos o desenho, passávamos o papel e começávamos a desenhar no desenho da outra. Dessa mitologia da coletividade, em que um desenho se compunha a partir das intervenções de todas as crianças, vimos mães d’água, caiporas, vós das matas e curupiras inscreverem relações com a lua, o mar, as matas, os animais.

As imagens agora retiravam os encantados de um certo isolamento e solidão que víamos antes e passavam a ganhar profundidade no acúmulo dos traços. Os encantados estavam envolvidos em espaços e tempos, numa expansão dos sentidos e dos vínculos que eles estabeleciam com o espaço do desenho. A força circular da gira se aprofundou nas relações entre encantados, espaço-tempo, onde estavam, o que carregavam nas mãos, se havia algo em torno deles, se era dia ou noite.

Estávamos Laura, Xica, Keila, Laís, Janairi, Cacá e Aurora. Cinco crianças e duas adultas, uma roda de mulheres. Foi um momento excitante de conversa sobre aqueles seres, novamente, sempre tinha alguém que conhecia alguém que já tinha visto um encantado e isto povoava nossas conversas entre o colorido.

\section{Escola parque quintal}

No dia da ciranda de desenhos, a hora deu aquela cambalhota e, de repente, era noite na escola e começou a chover. Estávamos na oca, um espaço circular da 
escola e sem paredes. Apenas uma pequena mureta com eucalipto divide interior e exterior, salão e quintal, escola e território. Dali, num giro de 360 graus, nos encontramos nessa relação dentro - fora da escola, numa situação particular, escola sem muros, grades, cercas, vigias, bedéis. Era a escola como dimensão expandida no quintal doméstico das casas adjacentes, da oca dos artesanatos, das trilhas entre as moradias, da represa e da mata.

É importante pontuar que a Educação Escolar Indígena, nas suas especificidades bilíngue e intercultural, assim como no currículo e em processos de aprendizagem diferenciados, preveem que a localização das escolas seja em terras habitadas pelas próprias comunidades. O pesquisador Paulo de Tássio Borges da Silva discorre de como a Kijetxawê Zabelê, em seu nascimento, é pensada como uma "construção circular", que deveria guiar o projeto arquitetônico como uma oca de cultura, "tipo pátio aberto, porém coberto, no mesmo formato arredondado para favorecer a prática do Awê e a realização de encontros" (SILVA, 2014, p. 163).

Havíamos terminado a ciranda, - o encontro propriamente dito, previsto pelo espaço - e era hora de conversa fiada e um tempo que paira ali, de se perceber diferente no mundo. Foi quando chegou um dos meninos, era o menor de todos, Jean, tinha uns dois anos, três, no máximo. Ele, Xica e Aurora sem verbalizarem nada, nenhum projeto, montaram quase como uma mágica, um parque dentro da oca. As cadeiras escolares, aquelas clássicas de plástico azul com um braço em que se apoia o caderno, estavam enfileiradas formando um meio círculo. Eles iniciaram uma travessia que começava numa das pontas e atravessava todas, como se pulassem pedras no rio ou qualquer outro trajeto da criança cujos obstáculos são o convite à aventura do corpo. Caminhavam numa fila barulhenta, riam sem parar e cruzavam as cadeiras, ora pisando no assento, ora no braço. Quando chegavam na última, mostrava-se o caráter infinito, cíclico do trajeto, corriam pelo chão até retomarem novamente a outra ponta. 
A chuva engrossou e afinou enquanto aquela intensa repetição das incontáveis travessias abria, por outro ângulo, um espectro infinito da relação entre brincadeira, escola e espaço na Kijetxawê Zabelê. A oca da escola, naquele ínterim, nos parecia algo telúrico, governado pelas crianças e sua imaginação num tipo de insubmissão do sentar e apoiar os cadernos. Estremeciam as imagens mais disciplinares das fileiras das carteiras, do brincar restrito ao horário do recreio e da sala como espaço cuja dinâmica é determinada pela professora.

\section{Do desenho incorporado ou o livro vivo}

No dia seguinte, decidimos construir os seres encantados em tamanho maior, com materiais como papelão, desenhando e incorporando os materiais do mato, como sementes, flores, galhos e outros, coletados pelas crianças. Era um domingo e isto é uma dimensão temporal fortíssima e poderosa subjacente a essa vivência. Expressa um vínculo escola, criança e tempo não cronometrado ou metrificado com ocorrência de dias letivos contados num calendário fixo. No caso, tampouco era uma atividade planejada com a participação das crianças autorizada pelas famílias em horário extraescolar. Fomos em uma visita, pensamos como convidá-las para fazer os encantados bem grandes, do tamanho delas. Levamos papelões e tínhamos a escola enquanto território expandido e nós como coletores.

A coleta das folhas, galhos, cascas e flores aconteceu como vínculo profundo das crianças com o território, vimos gestos corajosos, outros delicados. Nos alternávamos num caminhar amalgamado nas estradas largas, onde conversávamos embolados, e "um caminhar" enfileirado nas trilhas mais fechadas, aquelas que só elas viam e nos guiavam. Mostravam os achados umas às outras e iam pelos tantos caminhos, além da estrada traçada no chão, atravessavam pequenos desvios e depois voltavam ao trilheiro ou à estrada. Suas andanças costuravam um saber espacial vivo. 
E tudo isso, num pequeno trecho, era o caminho entre a escola e casa de Janairi, que precisava ser buscada naquele dia, pois a visita tinha sido uma surpresa, elas também não nos esperavam.

Aqui, novamente o espaço e o movimento eram nossos norteadores. É importante pensar que tudo isso se deu como fruto de um lugar tido como um espaço de educação, a Kijetxawê, a partir do par "experiência e sentido", como muito bem propõe Bondía (2002). O movimento estético de coleta das folhas e flores para a criação dos encantados, assim como a travessia de ser/estar no território pataxó da Kaí, nos possibilitou a relação entre o saber e a vida, sendo a experiência a tônica responsável pela elaboração daquilo que nos acontecia.

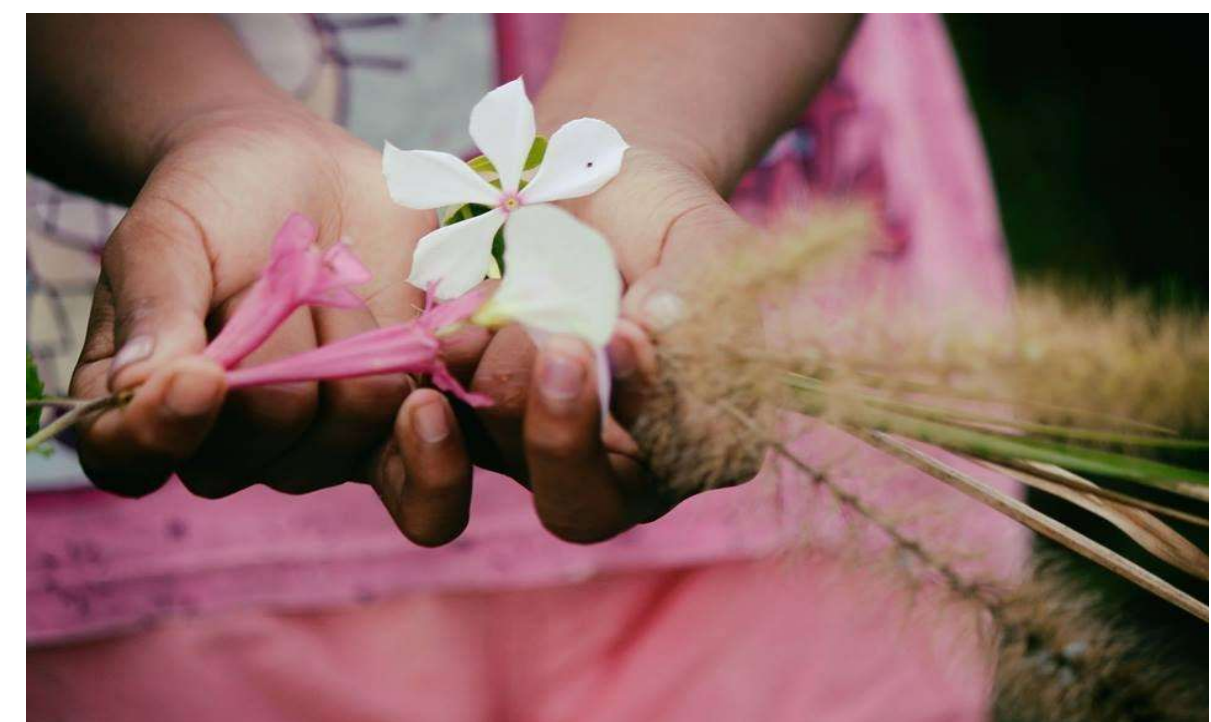

Figura 5 - uma das crianças coletando folhas na aldeia para criação dos encantados de papelão. Fonte: Acervo do projeto “Edições Zabelê" (foto de Tamykuã Pataxó).

Na especificidade desse espaço-tempo, portanto, é que surge e se elabora o que chamamos de livro-vivo, ou seja, de como fazíamos coisas com as palavras,

Quando fazemos coisas com as palavras, do que se trata é de como damos sentido ao que somos e ao que nos acontece, de como correlacionamos as palavras e as coisas, de como nomeamos o que vemos ou o que sentimos e de como vemos ou sentimos o que nomeamos. As palavras com que 
nomeamos o que somos, o que fazemos, o que pensamos, o que percebemos ou o que sentimos são mais do que simplesmente palavras. $E$, por isso, as lutas pelas palavras, pelo significado e pelo controle das palavras, pela imposição de certas palavras e pelo silenciamento ou desativação de outras palavras são lutas em que se joga algo mais do que simplesmente palavras, algo mais que somente palavras (BONDÍA, 2002, p. 21).

\section{Awê de encantaria}

$\mathrm{Na}$ volta à oca, montamos os encantados em arranjos vegetais, pinturas, sementes, papéis carimbados herdados da oficina de Rita Pataxó. Viraram um tipo de bonecos, alguns tinham rostos outros, como o boitatá, tinham máscaras. E agora eles tinham uma vida a ser experimentada com o próprio corpo, os bonecos encantados e as crianças tinham quase a mesma altura, e elas se colocavam atrás das figuras e, a partir dali, era impossível distinguir Laís, Xica, Aurora, Janairi. As pernas ou os pés em alguns momentos flagravam suas identidades, mas a atmosfera em que tudo se passou, onde podiam emitir sons, falas e muitas risadas - sempre - transmutou bonecos, crianças e escola num incrível awê de encantarias.

O awê aconteceu no dia seguinte à construção. Voltamos à escola com os bonecos e fizemos uma brincadeira na mata, com a caipora, a sereia, o caboclo de pena, caxinguelê e a vó da mata. O desafio que lançamos era levar os encantados para suas moradas, no que elas saíram em disparada rumo à represa. Descemos a represa cantando junto "caboclo de pena, escreva na areia, escreva na areia, o nome da aldeia". Ficamos muito impressionadas como as crianças toparam a brincadeira e a mata surgia ali como uma professora por onde elas faziam uma escuta profunda daqueles seres mágicos.

Quando entraram com o boitatá na sua morada, era um pedaço de mata fechada com uma trilha estreita, que só elas viam e nos apontavam a direção. Ali tudo 
era tão vivo e excitante, que as meninas começavam a se amedrontar um pouco dessa presença. Algumas riam, mas a que conduzia o boneco, que estava ali por detrás do boitatá, em cumplicidade corpo a corpo com o encantado revelou que não adentraria no fundo da mata, estava com medo, um medo revelador do quanto a vivência acionava tênues fronteiras da verdade e da ficção dos encantados. Nesse momento, o canto pataxó guiava e cantávamos: "caboclo de pena, escreva na areia, escreva na areia, o nome da aldeia, escreva na areia meu guerreirinho, o nome da aldeia". Assim, o medo não ancorava força, era atravessado por um assobio, um grito e correrias rumo a outra morada. Foi muito fugaz a experiência da morada do boitatá, minutos que duraram o tempo ancestral das ressonâncias dessa mitologia na vida das crianças.

As crianças andavam, subiam, desciam e paravam por detrás do que já agora chamamos de livro vivo e ativavam seus corpos, vibravam, imitavam sons. Todas nós ali vivíamos com o corpo todo aquela experiência. A experiência, então, era uma espécie de livro vivo e expandido, sem página, inscrito nas pegadas e nas escutas daquele território. Foi nessa andança com os encantados incorporados como extensões do corpo e expansões do território, que nascia, a cada passo, um território mítico e brincante, uma outra experiência escolar para nós, que temos sedimentados sentidos escolares logocentrados e disciplinares.

Assim como o livro vivo, vivíamos a escola como um espaço-tempo de aprendizagem infinito. A escola era a mata, a represa, as trilhas, as árvores e os encantados, os guias daquele aprender brincando. Instaurar a possibilidade de viver a história, de impregnação entre personagens, narrativas e espaços. Livro vivo frente à desestabilização das fronteiras entre narradores e espectadores e ao reposicionamento dos caminhos de elaboração das histórias. As crianças, ao mesmo tempo como narradoras, cuja escrita opera como escrita dos passos no território.

É recorrente no debate sobre a especificidade curricular das escolas indígenas, 
quilombolas e rurais encontrar críticas quanto à natureza dos conteúdos dos livros didáticos adotados, pois predomina o uso de materiais das escolas urbanas que são distribuídos de forma indiscriminada quanto aos contextos em que serão inseridos. $\mathrm{E}$ mesmo quando se insere determinados conteúdos nos livros, dada a obrigatoriedade da Lei 11.645/2008 (lei que determinada a abordagem de conteúdos étnicos referenciados), a metodologia de abordagem no processo de ensino e aprendizagem ignora a especificidade dos referidos contextos.

Ou seja, livros e processos de ensino e aprendizagem em profunda desconexão com as práticas e relações de cada comunidade. A experiência do livro vivo se refere ao deslocamento efetivo de princípios metodológicos, de conteúdos e de relações de aprendizagem. O livro vivo existe mesmo antes de ser impresso no papel e não corresponde a uma atividade indicada para ser executada. O caminho traçado se estabelece em outra direção, advém do entrecruzamento entre memória, ancestralidade, território e escola, nasce de uma experiência não escolar, não formal e se estabelece numa relação. E isso são princípios com relevante força para o fortalecimento dessas comunidades escolares.

Na Lei de Diretrizes e Bases da Educação, aprovada em 17 de dezembro de 1996, está expressa, no âmbito da Educação Escolar Indígena, a "elaboração e publicação sistemática de material didático específico e diferenciado" (SILVA, 2014, p. 74). Dessa forma, é interessante reconhecer o surgimento de materiais como "Com a terra construímos nossa história", de autoria de Luciene Pataxó, publicação construída a partir de oficinas com professores e estudantes pataxó da aldeia Muã Mimatxi, em Itapecerica, Minas Gerais, que redimensionam, em seus encaminhamentos didáticos, a experiência.

Dividido em quatro capítulos, relacionados a uma série de conteúdos, o desenho e as perguntas são norteadores do primeiro capítulo "Conversando sobre", seguido do 
"Pesquisando sobre", em que a "pesquisa", algo abertamente relacionado ao conhecimento tradicional dos mais velhos no espaço escolar, é feita "pelo olhar e pela fala" e é tida como "uma vida contínua que liga um tempo a outro, é uma forma de viver no mundo, de viver no espaço". Somado a isso, encontramos ainda os capítulos que disparam o "Trabalho com a terra" e "Oficina de produção", relacionados a vivências de práticas, coroados por uma noção de textos conjuntos produzidos na articulação dialógica entre os estudantes e professores (PATAXÓ, 2012, p. 12).

A necessidade, portanto, de materiais didáticos específicos e diferenciados vem ao encontro dos novos debates em torno dos letramentos que, extrapolando as habilidades do ler e escrever, precisam ser compreendidos em relação a cada contexto de aprendizado como "um conjunto de práticas sociais cujos modos específicos de funcionamento têm implicações importantes para as formas pelas quais os sujeitos envolvidos nessas práticas constroem relações de identidade e poder" (KLEIMAN, 1995, p. 11).

\section{Das despedidas}

Entrei na casa de Sueli e os encantados estavam todos pendurados nas paredes. Alguns estavam diferentes, principalmente a mãe d'água e, quando Sueli viu o meu encantamento, me contou que Xica tinha ficado a noite inteira cortando, colando e desenhando naqueles seres que do papelão ganharam vida. Foi todo mundo dormir e ela ficou aí, disse assim.

Era o último dia na aldeia. Pensava em como a casa de Sueli, de tão próxima da escola, era um desdobramento dela. E, ao mesmo tempo, a escola era o quintal - do tamanho da mata - das crianças de Sueli.

Nos reunimos ali, Xica, Keilinha, Talita e fomos chamar em suas casas Janari e Laisinha para irmos à praia e levarmos à mãe dágua, no mar, o que fizemos. As meninas 
ficaram excitadas de irem ao mar, elemento tão presente nas nossas rodas de desenho dias atrás.

Foi numa risadaria danada quando atravessamos o Rio do Peixe Pequeno e chegamos ao mar. Lá pousamos a sereia na areia, bem pertinho das águas. Fizemos uma roda perto dela, fechamos os olhos e fomos escutar para ver se ouvíamos a mãe dágua.

Não lembro quem deu uma risada que fez com que todas nós abríssemos os olhos e sorríssemos também. Foi aí que começou a brincadeira. O plano era cobrir a sereia de encantos do mar: conchas, algas e o que mais aparecesse. A praia, então, tornou-se um baú de tesouros a céu aberto. A sereia ganhou um cabelo lindo de águas, olhos de concha, brincos de pedrinhas do mar e mais um montão de tesouros achados na areia e nas águas.

Quando parecia pronta, deixamos ela ali, ao som do barulho das águas e fomos brincar no mar. Nessa hora, éramos nós as sereias, com algas nos cabelos, conchas nas mãos e muito brilho no sorriso que surgia das brincadeiras, das conversas e do desfrute do mar, território pataxó. O Sol foi caindo e nos encaminhamos para voltar para a aldeia. Levamos a sereia de volta, subimos a estrada e, entre frutinhas que apareciam no caminho, cantando músicas, voltamos encantadas para casa, para dependurar novamente a sereia encantada na parede da casa de Xica e Keila, filhas de Sueli, onde nos despedimos com saudade.

\section{Do livro vivo ao livro impresso}

Aqui relatamos algumas intensidades e vivências de onde e de quando nasceram variadas pequenas porções-ferramentas-fragmentos do livro "Kijetxawê Zabelê - Aldeia Kaí". É um livro-encontro agenciado na escola e seu vasto e intangível território, expandido em muitos nascimentos, brotamentos e germinações. A escrita 
disparada na oficina com as crianças reescreveu-se em vários momentos, de conversas, de relatos, de muitas vezes que elas e os anciãos contaram e recontaram a mesma história, sempre outra.

A mãe d'água, o encanto de Xica, as bruxas e a Zabelê como aparições recorrentes, sempre presentificadas nos relatos e contações, enredam-se no livro na história impressa a seguir. O texto articulado aos desenhos, muitos deles feitos durante a ciranda de desenhos, tenta transportar, o que é possível, para o livro impresso. Dimensões viscerais, vívidas e absolutamente indizíveis ocupam um limbo na passagem tentativa do livro vivo ao livro impresso. Muita coisa se perde, mas muito, em suspensão, fica à espera de novas leituras, na abertura imensa para o criar dos olhos livres das crianças, da potência de suas leituras do mundo e das palavras.

Sentimos, com esse percurso, que o livro físico nasce de um livro vivido, na incorporação de rastros e registros às páginas impressas. A publicação guarda ainda seu poder de afetar, de poder conectar seus leitores a um sentimento de autoria e pertencimento.

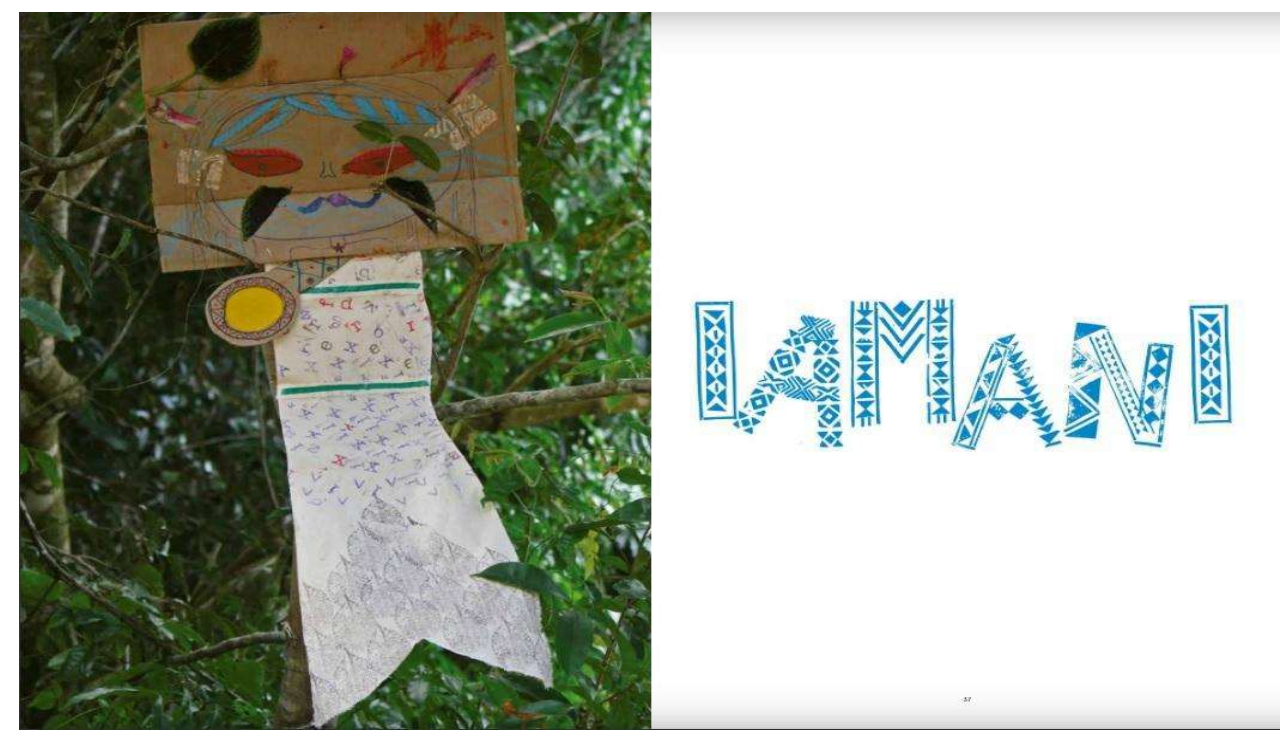

Figura 6 - Páginas do livro "Kijetxawê Zabelê - Aldeia Kaí". Fonte: Castro e Fonseca (2019, p. 38-39). 
Quando essa história - mesmo remixada das experiências que as originaram retorna à aldeia, as crianças continuam reconhecendo-a como delas. Riem, lembram do nome das bruxas, olham os desenhos com encantamento. O livro, então, permanece encantado, guardando mistérios da ordem do invisível. No movimento do tempo do livro, em seu awê pelas mãos, pelas leituras, tudo pode estar prestes a se recriar.

Era uma vez uma mãe d'água.

Ela era linda, inteligente, muito, mas muito esperta.

Xica um dia decidiu chamar por ela. Caminhou pela mata e chegou no mar. Lá encontrou a mãe d'água na praia do Moreira. Muito animada, disse pra ela:

-Oi, mãe-d'água! Você é linda!

Assim que Xica falou com a sereia, se lembrou de sua vó dizendo que se ouvisse a voz dela poderia cair em seu encanto. Então ela saiu correndo no mato, rindo muito de felicidade de ter encontrado com a mãe d'água.

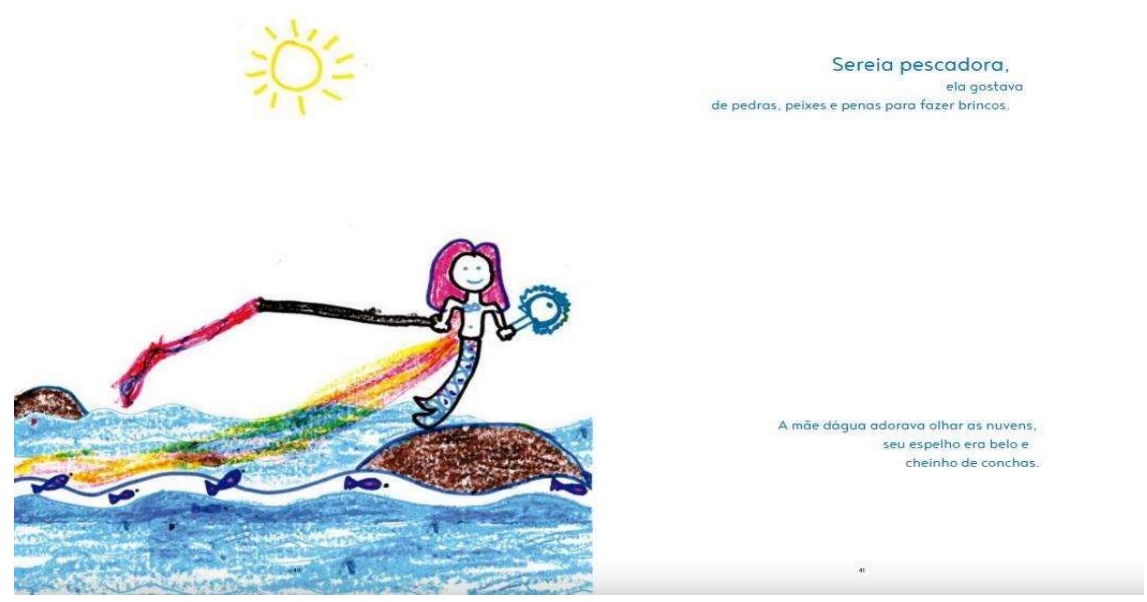

Figura 7 - Páginas do livro "Kijetxawê Zabelê - Aldeia Kaí". Fonte: Castro e Fonseca (2019, p. 42-43). 


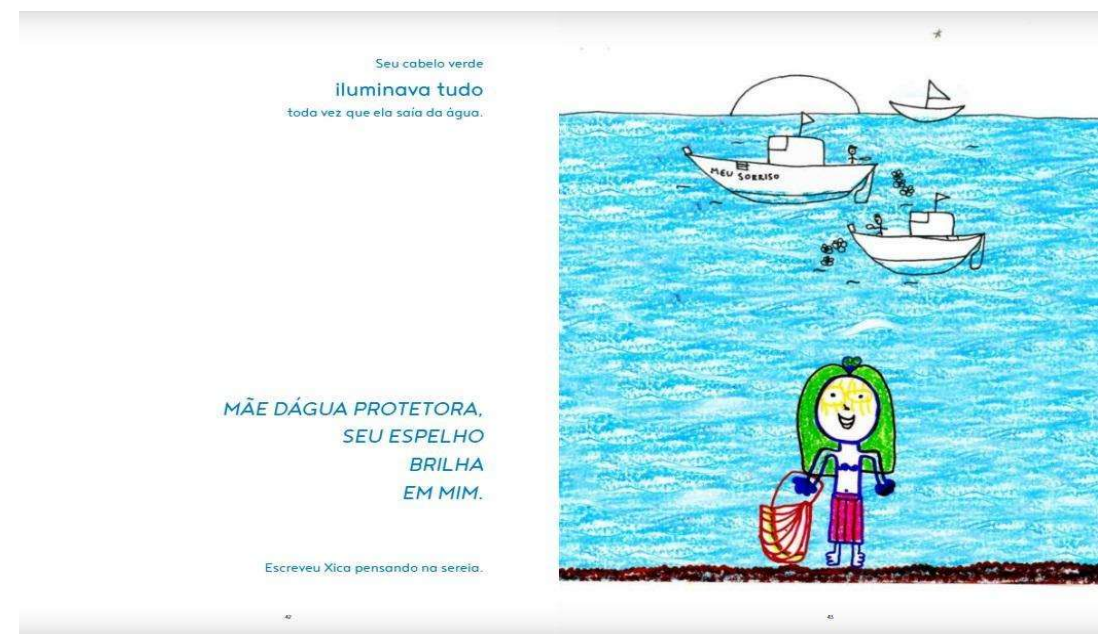

Figura 8 - Páginas do livro "Kijetxawê Zabelê - Aldeia Kaí".

Fonte: Castro e Fonseca (2019, p. 44-45).

Foi aí que surgiram duas bruxas: Fernanda e Maria.

E agora?

Xica estaria em perigo?

As duas bruxas brigaram com ela e disseram que ela não podia ficar ali, que a mata era delas.

Oquê?

A mata era delas?

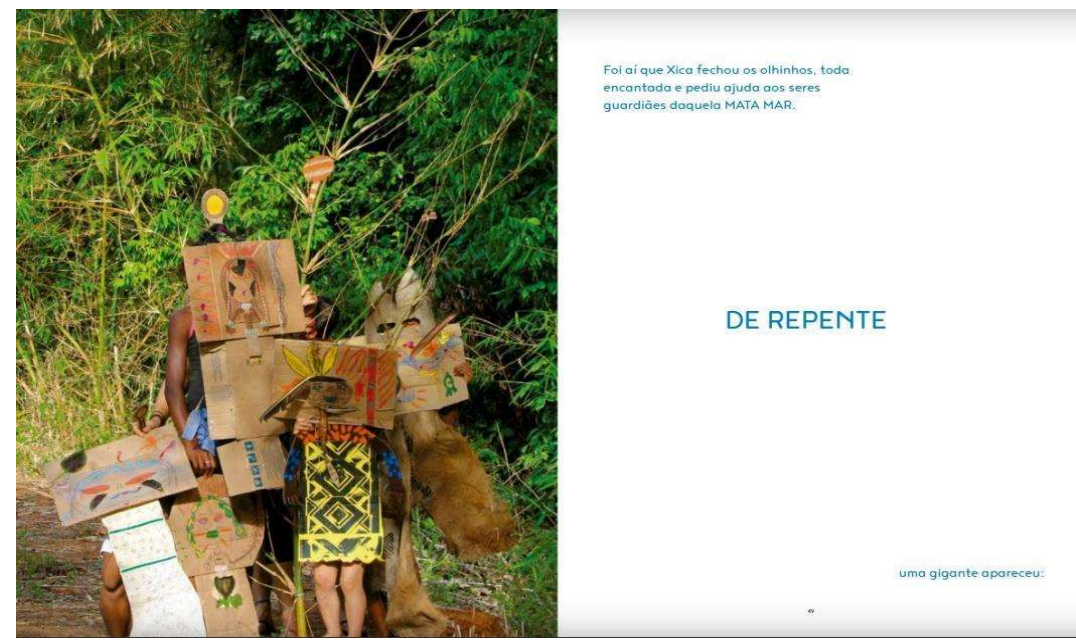

Figura 9 - Páginas do livro "Kijetxawê Zabelê - Aldeia Kaí". Fonte: Castro e Fonseca (2019, p. 50-51). 
Se Xica morava ali e sua mãe e suas irmãs e sua vó e seus parentes todos?

Foi aí que Xica fechou os olhinhos, toda encantada e pediu ajuda aos seres guardiões daquela mata mar

De repente...

Uma gigante apareceu:

A Vó da Mata. E expulsou elas dali.

Aliás! Não!

Transformou elas em javalis (CASTRO; FONSECA, 2019, p. 36-51).

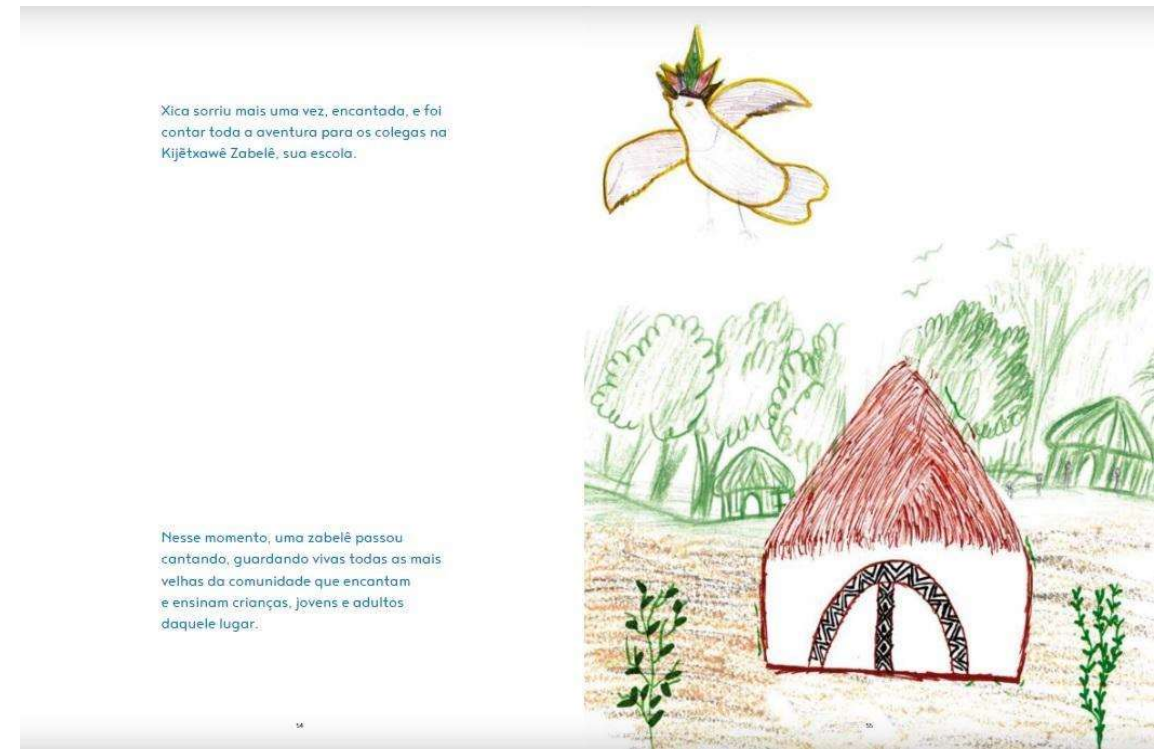

Figura 10 - Páginas do livro "Kijetxawê Zabelê - Aldeia Kaî". Fonte: Castro e Fonseca (2019, p. 56-57).

\section{Referências}

BONDÍA, J. L. Notas sobre a experiência e o saber de experiência. Rev. Bras. Educ., Rio de Janeiro, v. 19, p. 20-28, jan./abr. 2002. Disponível em: http://www.scielo.br/scielo.php?script=sci_arttext\&pid=S141324782002000100003\&lng=pt\&nrm=iso. Acesso em: 01 mar 2020. 
CASTRO, L.; FONSECA, C. (org.). Kijetxawê Zabelê: Aldeia Kaí. 1. ed. Salvador: Sociedade da Prensa: EDTÓRA, 2019.

KLEIMAN, A. Os significados do letramento: uma nova perspectiva sobre a prática social da escrita. Campinas: Mercado da Letras, 1995.

PATAXÓ, L. Com a terra construímos a nossa história. Belo Horizonte: Literaterras: FALE/UFMG, 2012.

SILVA, P. T. B. As relações de interculturalidade entre conhecimento científico e conhecimentos tradicionais na Escola Estadual Indígena Kijetxawê Zabelê. 2014. 121 f. Dissertação (Mestrado em Educação) - Universidade Federal de Sergipe, São Cristóvão, Sergipe, 2014. Disponível em:

https://ri.ufs.br/bitstream/riufs/4814/1/PAULO_TASSIO_BORGES_SILVA.pdf. Acesso em: 01 mar. 2020.

Enviado em: $26 / 11 / 2019$

Aprovado em: 04/03/2020 